\title{
OPEN Big trees drive forest structure patterns across a lowland Amazon regrowth gradient
}

\author{
Tassiana Maylla Fontoura Caron ${ }^{1}$, Victor Juan Ulises Rodriguez Chuma ${ }^{2}$, \\ Alexander Arévalo Sandi ${ }^{3} \&$ Darren Norris ${ }^{1,3,4} \bowtie$
}

Degraded Amazonian forests can take decades to recover and the ecological results of natural regeneration are still uncertain. Here we use field data collected across 15 lowland Amazon smallholder properties to examine the relationships between forest structure, mammal diversity, regrowth type, regrowth age, topography and hydrology. Forest structure was quantified together with mammal diversity in 30 paired regrowth-control plots. Forest regrowth stage was classified into three groups: late second-regrowth, early second-regrowth and abandoned pasture. Basal area in regrowth plots remained less than half that recorded in control plots even after 20-25 years. Although basal area did increase in sequence from pasture, early to late-regrowth plots, there was a significant decline in basal area of late-regrowth control plots associated with a decline in the proportion of large trees. Variation in different forest structure responses was explained by contrasting variables, with the proportion of small trees ( $\mathrm{DBH}<20 \mathrm{~cm}$ ) most strongly explained by topography (altitude and slope) whereas the proportion of large trees $(\mathrm{DBH}>60 \mathrm{~cm})$ was explained by plot type (control vs. regrowth) and regrowth class. These findings support calls for increased efforts to actively conserve large trees to avoid retrogressive succession around edges of degraded Amazon forests.

Tropical forests provide goods and services to human populations. Yet tropical regions show worrying rates of forest loss with an elevated loss / gain ratio and a statistically significant trend in annual forest loss of $2101 \mathrm{~km}^{2} /$ year ${ }^{1}$. One option to revert tropical forest loss is the restoration of degraded forests and deforested landscapes ${ }^{2,3}$. Although the post-disturbance restoration of forest ecosystems often involves passive restoration strategies (i.e. natural regeneration), the ecological results of this type of restoration are still uncertain ${ }^{2-4}$.

Continuing widespread forest losses across Amazonia compromises vital ecosystem services such as carbon storage, regulation of hydrological cycles and climate patterns ${ }^{5-7}$. Riverside forests are particularly threatened and suffer losses due to the conversion of forest cover to pastures, compromising the maintenance of water flows ${ }^{8}$. The recovery of degraded areas is necessary to recuperate the standing forest value and the Amazon offers an excellent recovery opportunity due to its natural potential for regeneration ${ }^{9,10}$. Yet, the regrowth rate of degraded Amazon forests can be slow, as abandoned areas are typically on compacted poor quality soils ${ }^{11,12}$ and due to the high structural and biological diversity of the original forests ${ }^{13}$.

Separating the complex interactions driving recruitment and recovery patterns of highly diverse Amazon forests is challenging ${ }^{2,3,14,15}$, yet we know that different faunal groups can modulate and generate key impacts ${ }^{16-19}$. Indeed, the successional trajectory of natural regeneration in degraded forests can depend strongly on the concomitant recovery of faunal diversity and associated ecosystem services (e.g. seed dispersal) ${ }^{20-22}$. For example, seed predation by both vertebrates and invertebrates ${ }^{23,24}$ can limit germination and subsequent recruitment ${ }^{22}$. Long-term experiments have demonstrated the impact of vertebrates on recruitment, showing how this group contributes to the maintenance of tropical forest species and structural diversity ${ }^{25-28}$.

Amazon mammals are important component of forest diversity ${ }^{25,29}$ including carbon ${ }^{28}$ and biomass cycles ${ }^{18}$. Mammals can also play an important role in the successional trajectory and recovery of degraded areas as dispersers and predators of both seeds and seedlings $\mathrm{s}^{23}$. Mid- and large-bodied mammals (weight $>1 \mathrm{~kg}$ ) can disperse a large numbers of seeds over long distances ${ }^{23,30}$. For example, lowland tapirs can travel over $4 \mathrm{~km}$ in a

\footnotetext{
${ }^{1}$ Programa de Pós-Graduação Em Biodiversidade Tropical, Universidade Federal Do Amapá (UNIFAP), Rod. Juscelino Kubitscheck, Km 02, Macapá, AP 68902-280, Brazil. Facultad de Ciencias Forestales, Universidad Nacional de La Amazonia Peruana (UNAP), Pevas 5ta cuadra, Iquitos, Peru. ${ }^{3}$ Programa de Pós-Graduação Em Ecologia, Instituto Nacional de Pesquisas da Amazônia (INPA), Av. André Araújo 2936, Petrópolis, Manaus, AM 69067-375, Brazil. " Coordenação de Ciências Ambientais, Universidade Federal Do Amapá (UNIFAP), Rod. Juscelino Kubitschek Km 02, Macapá, AP 68902-280,Brazil.『email: dnorris75@gmail.com
} 


\begin{tabular}{|c|c|c|c|c|}
\hline Working hypothesis/model & Variables & Source & Description/ecological relevance & Supporting references \\
\hline \multirow{3}{*}{ Topography } & Plot type & In situ & $\begin{array}{l}\text { Categorical factor with two levels: control and regrowth. } \\
\text { Included in all models }\end{array}$ & \\
\hline & Altitude & SRTM-DEM & $\begin{array}{l}\text { Altitude is a driver and modulator of species distribution } \\
\text { patterns from microhabitat to biogeographic scales. Altitude } \\
\text { not only affects soil, water availability, climate and a myriad of } \\
\text { other abiotic and biotic variables }\end{array}$ & $13,35-37$ \\
\hline & Slope & SRTM-DEM & Slope affects soil, water availability and tree mortality rates & \\
\hline \multirow{2}{*}{ Hydrology } & TWI & SRTM-DEM & $\begin{array}{l}\text { Topographic wetness index accounts for the topographic } \\
\text { control of water movement in sloped landscapes and the } \\
\text { associated control on soil moisture }\end{array}$ & 38 \\
\hline & Drainage proximity & SRTM-DEM & $\begin{array}{l}\text { Combination of water gravitational potential (Height above } \\
\text { the nearest drainage (HAND)) and soil drainage (Horizontal } \\
\text { distance from nearest drainage (HDND)) }\end{array}$ & $39-41$ \\
\hline Regrowth class & Regrowth class & In situ: interview & $\begin{array}{l}\text { Land-use history has a strong influence on rates of forest } \\
\text { recovery. Categorical factor with three levels of regrowth class } \\
\text { derived from the land-use history: late second-regrowth forest, } \\
\text { early second-regrowth and pasture }\end{array}$ & $16,36,42,43$ \\
\hline \multirow{2}{*}{ Time } & Years since last use & In situ: interview & \multirow{2}{*}{ Time is a major determinant of forest succession } & \\
\hline & Years since initial clearing & In situ: interview & & \\
\hline \multirow{2}{*}{ Mammals } & Species richness & In situ: camera-trap images & \multirow{2}{*}{ Mammal diversity is positively related to tree biomass } & \multirow{2}{*}{$17,18,28,44$} \\
\hline & Functional diversity & In situ: camera-trap images & & \\
\hline
\end{tabular}

Table 1. Explanatory variables.

\begin{tabular}{|c|c|c|c|c|c|c|c|c|c|c|}
\hline \multirow{2}{*}{$\begin{array}{l}\text { Regrowth } \\
\text { class }\end{array}$} & \multirow[b]{2}{*}{ Sites/Plots } & \multirow[b]{2}{*}{ Site Size (ha) } & \multicolumn{2}{|l|}{ Distance } & \multicolumn{2}{|c|}{ Forest cover $(\%)$} & \multicolumn{2}{|c|}{ Tree BA $\left(\mathrm{m}^{2} / \mathrm{ha}\right)$} & \multicolumn{2}{|c|}{ Large tree $\mathrm{BA}\left(\mathrm{m}^{2} / \mathrm{ha}\right)$} \\
\hline & & & River (m) & Town $(\mathbf{k m})$ & $1 \mathrm{~km}$ & $5 \mathrm{~km}$ & Reg & Cont & Reg & Cont \\
\hline Late & $5 / 10$ & $5.8(2.0-12.0)$ & $\begin{array}{l}288.15 \\
(110-554)\end{array}$ & $40.4(35.0-45.0$ & $\begin{array}{l}91.5 \\
(87.4-95.4) \\
\end{array}$ & \begin{tabular}{|l|}
97.4 \\
$(96.4-98.5)$ \\
\end{tabular} & $\begin{array}{l}17.6 \\
(11.5-25.3)\end{array}$ & $\begin{array}{l}35.8 \\
(21.7-47.4) \\
\end{array}$ & $1.5(0.0-7.7)$ & $11.4(0.0-22.3)$ \\
\hline Early & $5 / 10$ & $2.4(1.0-4.5)$ & $\begin{array}{l}348.5 \\
(150-554)\end{array}$ & $\begin{array}{l}38.2 \\
(30.0-43.7)\end{array}$ & $\begin{array}{l}90.7 \\
(87.1-96.0)\end{array}$ & $\begin{array}{l}97.2 \\
(96.4-98.4)\end{array}$ & $11.1(4.7-19.2)$ & \begin{tabular}{|l|}
49.3 \\
$(34.6-76.5)$
\end{tabular} & $0.0(0.0-0.0)$ & $20.8(0.0-44.2)$ \\
\hline Pasture & $5 / 10$ & $8.7(6.8-9.9)$ & $\begin{array}{l}266.8 \\
(170-461)\end{array}$ & $\begin{array}{l}32.8 \\
(26.8-40.8)\end{array}$ & $\begin{array}{l}88.8 \\
(85.7-91.1)\end{array}$ & $\begin{array}{l}96.9 \\
(95.5-98.5)\end{array}$ & $5.8(0.0-15.9)$ & \begin{tabular}{|l|}
47.1 \\
$(32.6-64.8)$
\end{tabular} & $0.0(0.0-0.0)$ & $\begin{array}{l}24.0 \\
(12.0-41.2)\end{array}$ \\
\hline Totals & $15 / 30$ & $5.6(1.0-12.0)$ & $\begin{array}{l}301.1 \\
(110-554)\end{array}$ & \begin{tabular}{|l|}
37.1 \\
$(26.8-45.0)$
\end{tabular} & \begin{tabular}{|l|}
90.4 \\
$(85.7-96.0)$
\end{tabular} & \begin{tabular}{|l|}
97.2 \\
$(95.5-98.5)$
\end{tabular} & $11.5(0.0-25.3)$ & $\begin{array}{l}44.1 \\
(21.7-76.4)\end{array}$ & $0.5(0.0-7.7)$ & $18.8(0.0-44.2)$ \\
\hline
\end{tabular}

Table 2. Summary of survey locations. Characteristics of 15 sites used to study forest structure. Values are means with ranges in parentheses.

day $^{31}$ and disperse seeds of more than 70 tree species ${ }^{32}$. The loss of mid- to large-bodied mammals may release some plant species from herbivory and increase their dominance, which subsequently decreases tropical forest biodiversity ${ }^{33,34}$.

Given the need to understand the patterns of forest structure in Amazonian forests, here we aim to identify how biotic and abiotic factors (Table 1) can explain patterns in forest structure across a successional gradient in 15 lowland (90-120 masl) smallholder properties in the eastern Brazilian Amzon. These sites were surrounded by a matrix of continuous closed canopy forest cover (Table 2), a configuration far different from more widely studied fragmented landscapes. We compare 5 forest structure attributes across late second-regrowth, early second-regrowth and abandoned pasture plots to examine how forest structure changes in relation to topography, hydrology, regrowth class, time and mammal diversity.

\section{Results}

Variation in stand structure variables. There were clear differences in forest structure between control and regrowth plots (Fig. 1). On average control plots had increased basal area and increased proportion of large trees (Fig. 1). In contrast regrowth plots tended to have increased proportion of small trees $(<20 \mathrm{~cm} \mathrm{DBH})$.

The number and basal area of living trees tended to increase with altitude and this relationship was stronger in regrowth areas (Fig. 2). The relationship with altitude was strongly affected by low lying (90 masl) pasture plots with no trees that generated significant leverage on the linear relationship (Fig. 2).

Basal area ranged from 0 to $76.4 \mathrm{~m}^{2} /$ ha across the 30 survey plots (Table 2), with control plots showing an average fourfold increase in basal area compared with regrowth plots (mean basal area 44.1 and $11.5 \mathrm{~m}^{2} / \mathrm{ha}$, control and regrowth respectively, Fig. 2). The patterns in plot basal area also differed between regrowth classes (Fig. 3, Supplementary Table S1). There was a significant interaction between plot type (control/regrowth) and regrowth stage, with basal area increasing across pasture, early and late regrowth plots but control plots showing the opposite trend, with basal area decreasing significantly in late-regrowth control plots (Fig. 3).

There was a highly significant positive linear relationship between overall basal area and large tree basal area $\left(\mathrm{F}_{1,28}=127.5, \mathrm{R}^{2}=0.82, P<0.0001\right)$. The basal area of large trees decreased significantly in regrowth compared 


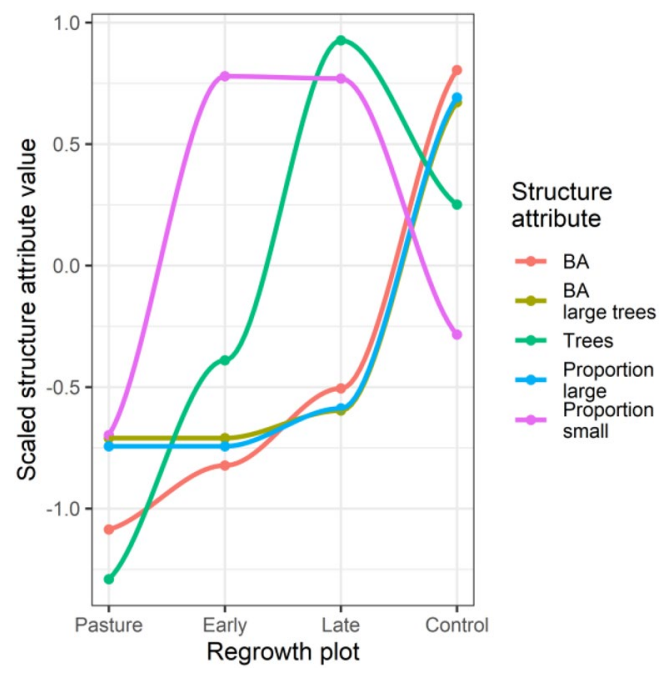

Figure 1. Forest structure changes across a lowland forest regrowth gradient. Showing mean values of five forest structure attributes recorded in 30 plots ( 15 control and 15 regrowth). Regrowth plot shows differences between control, late second-regrowth, early second-regrowth and pasture plots. Values are scaled (centered and scaled by the standard deviation) to enable simultaneous visual comparison of the different attributes. The lines are from LOESS smoothing as guides to aid visual interpretation.
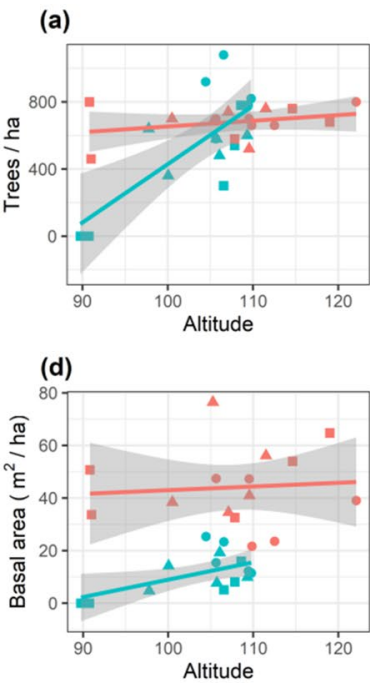

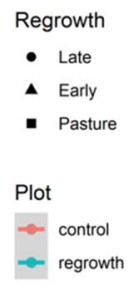

Regrowth

- Late

- Early

- Pasture

Plot

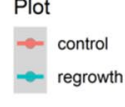

(b)

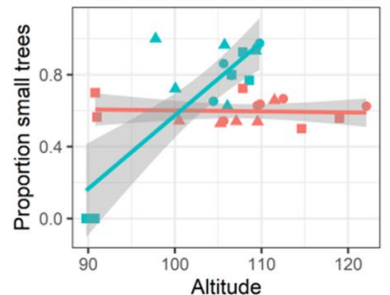

(e)

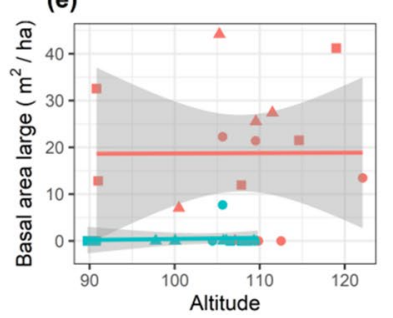

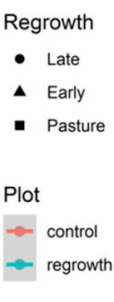

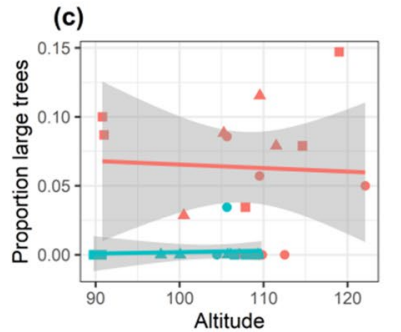

Regrowth

- Late

- Early

- Pasture

Plot

- control

- regrowth

Figure 2. Forest structure along a lowland Amazon regrowth gradient. Showing trends in (a) number of trees $(>10 \mathrm{~cm} \mathrm{DBH})$ per ha, $(\mathbf{b})$ proportion of small trees $(10-20 \mathrm{~cm} \mathrm{DBH}),(\mathbf{c})$ proportion of large $(>60 \mathrm{~cm} \mathrm{DBH})$ trees, (d) basal area and (e) basal area of large $(>60 \mathrm{~cm} \mathrm{DBH})$ tree in 30 plots (15 control and 15 regrowth). Lines and shaded areas are mean values and 95\% confidence intervals from linear models illustrating trends in basal area with increasing altitude (masl). Points with different shapes represent different regrowth classes.

with control plots (Fig. 3). On average large trees accounted for $42 \%$ of the basal area in control plots compared with only $4 \%$ in regrowth plots (Table 2$)$. Indeed a single large tree $(>60 \mathrm{~cm} \mathrm{DBH})$ was recorded only once in a late-regrowth plot. This relationship was also reflected in the decline in basal area of late-regrowth control plots (Fig. 3), which was associated with a decline on the proportion of large trees that accounted for a reduced $31 \%$ of the basal area in late-regrowth control plots (Table 2).

Relationships between forest structure, mammal diversity and environmental variables. Mammal diversity varied considerably across the survey plots (Fig. 4). There appeared to be a tendency for basal area to increase with mammal diversity in Late-regrowth plots, yet basal area was only weakly associated with mammal diversity within the different regrowth classes (Fig. 4). Indeed, the diversity of mammals was found to be only weakly informative for explaining the basal area of trees across the 30 sample plots (Table 3).

Comparison of models showed that plot type (control $v$ regrowth) and topography were the most important first ranked variables for the five forest structure attributes (Table 3). The most simple model including only 
(a)

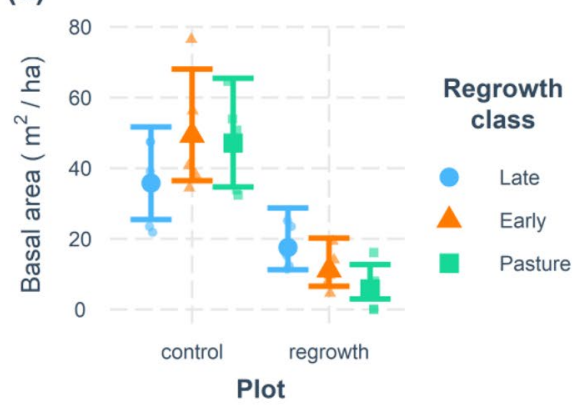

(c)

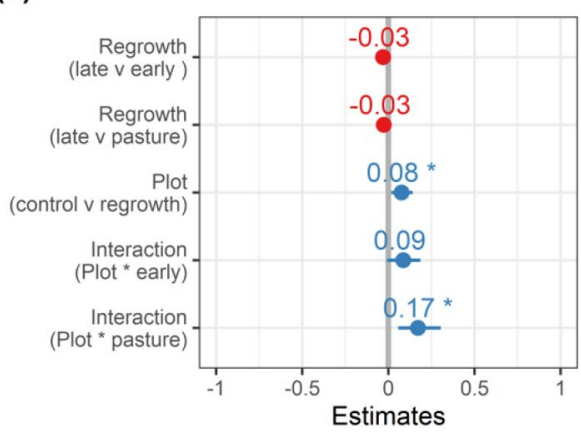

(b)

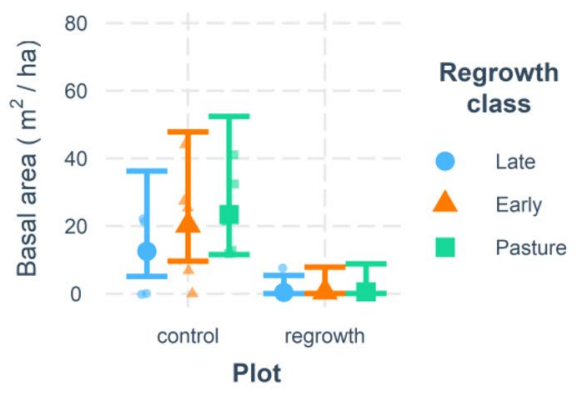

(d)

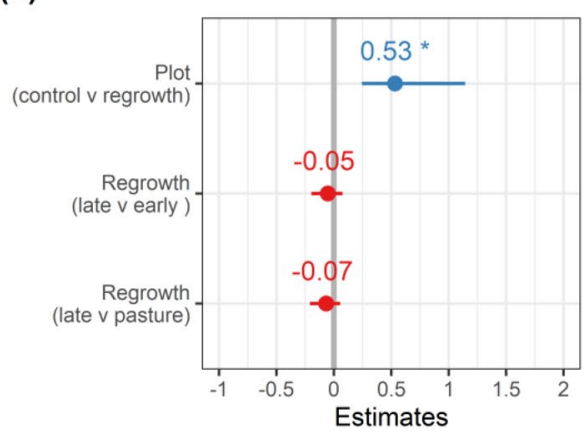

Figure 3. Basal area changes across a lowland forest regrowth gradient. The basal area of all $(\mathbf{a}, \mathbf{c})$ and large $(\mathbf{b}, \mathbf{d})$ living trees were recorded in 30 plots ( 15 control and 15 regrowth). Regrowth class shows differences between late second-regrowth, early second-regrowth and pasture plots contrasted with control forest plots. Top row shows Generalized Linear Model (GLM) predictions (mean and 95\% confidence intervals) for basal area of (a) all and (b) large trees. Bottom row is the associated Forest-plot of the most parsimonious GLMs testing for interactions between regrowth class, plot type and years since last use in the basal area of (c) all and (d) large trees. Forest-plots show coefficient estimates and standard errors.

plot type explained more than $50 \%$ of model deviance for all forest structure attributes except for the number of trees $(\mathrm{DBH}>10 \mathrm{~cm})$. Plot type and regrowth class were both included in the $95 \%$ confidence set of models for the basal area of large trees (Table 3). In contrast Topography was the most important (first ranked) model for the number of trees, proportion of small trees and tree basal area (Table 3). Mammal diversity, Time and Hydrology models were not well supported and were not included in the $95 \%$ confidence set of models for any of the forest structure attributes (Table 3 ).

\section{Discussion}

We integrate field and remotely sensed data to establish support for the relative importance of different variables explaining patterns in forest structure across a lowland Amazon regrowth gradient. We establish that different variables are supported for different structure attributes. Here we discuss these findings in terms of prospects for the passive restoration of degraded Amazon forests.

The mean basal area value from our 15 control plots $\left(44.1 \mathrm{~m}^{2} / \mathrm{ha}\right)$ was close to the mean from 42 Guyana Shield forest plots $\left(43.4 \mathrm{~m}^{2} / \mathrm{ha}\right.$, range $\left.10-65 \mathrm{~m}^{2} / \mathrm{ha}\right)$ in French Guiana ${ }^{35}$. The results from Molto et al. ${ }^{35}$ were obtained from an extensive survey of $0.5-1$ ha plots. Although our plot size was smaller compared to Molto et al. ${ }^{35}$, the similarity in mean values suggests that our plots do provide a representative sample of forest structure in the regrowth areas. The basal areas obtained from our regrowth plots followed a similar trajectory to those reported from abandoned pasture in Costa $\mathrm{Rica}^{36}$, where the most recently abandoned pasture plots $(<14$ year $)$ had mean basal area of $13.5 \mathrm{~m}^{2} /$ ha, with basal area increasing to $26.1 \mathrm{~m}^{2} /$ ha after $21-30$ year ${ }^{36}$.compared with 11.1 and $17.6 \mathrm{~m}^{2} /$ ha respectively in our Early (1-5 year) and Late (20-25 year) regrowth plots. This also follows a similar pattern to values reported from 370 successional forest plots in the Brazilian Amazon, with basal area values typically $<10 \mathrm{~m}^{2} /$ ha in early stages ( $<5$ year) and reaching $25 \mathrm{~m}^{2} /$ ha after 15 years ${ }^{45}$.

Although results from lowland forest sites in Costa Rica suggest rapid recovery of pasture areas ${ }^{36}$ this could be related to the substantially lower basal area in the seven old growth reference plots $\left(26.1 \mathrm{~m}^{2} / \mathrm{ha}\right.$, range $19.3-32.2$ $\mathrm{m}^{2} / \mathrm{ha}$ ) compared with those in our study area. Our results are similar to those reported from the central Amazon, where $25 \mathrm{y}$ of regrowth restored half of the mature-forest biomass ${ }^{42}$. A recent analysis of 45 Neotropical secondary forest study sites found that secondary forests in the lowland tropics reach 90 percent of old growth biomass in a median time of $66 \mathrm{yr}^{13}$. Our findings do suggest nuanced difference in successional trajectories. Basal area increased rapidly in early regrowth stages and this could be explained by the less intensive land use (i.e. lack of pasture) and the proximity to large areas of intact forest. In contrast basal area of late-regrowth areas was less than those reported from other areas ${ }^{36,45}$. This could be related to soil productivity, as previous studies 
(a)

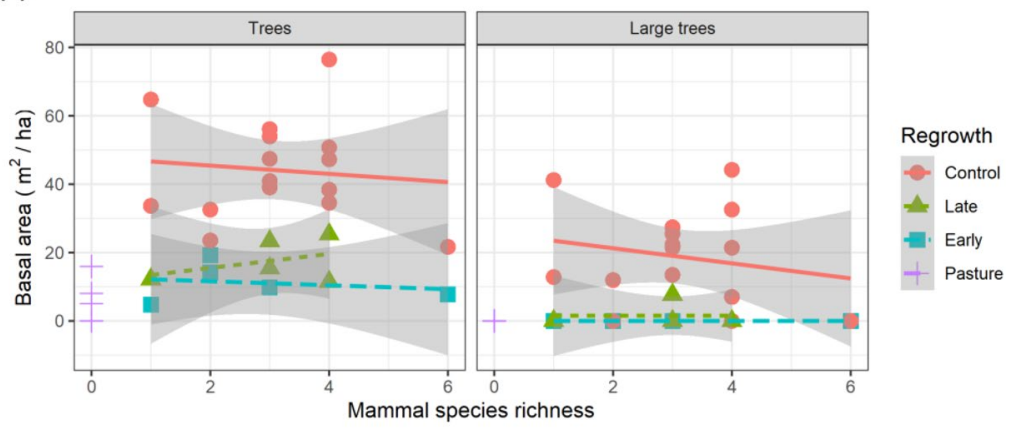

(b)

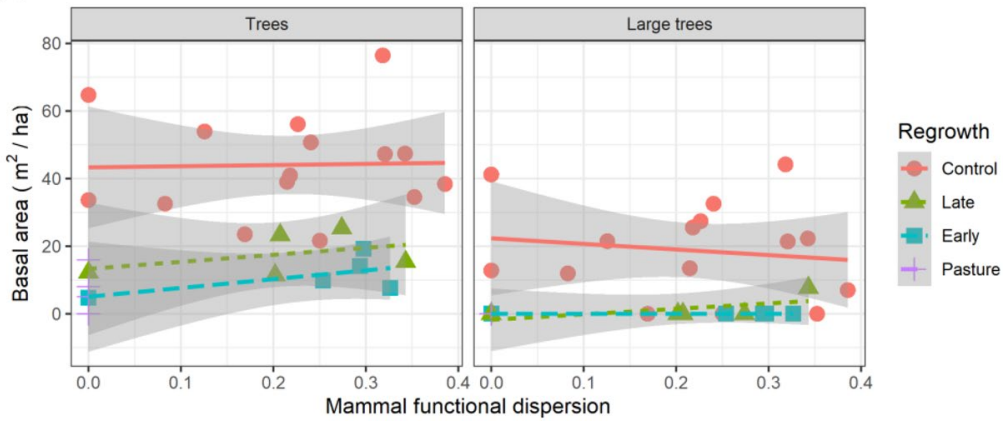

Figure 4. Mammal diversity and basal area across a lowland forest regrowth gradient. The basal area of (a) all and (b) large living trees were recorded together with the diversity (species richness and functional dispersion) of terrestrial mammals in 30 plots ( 15 control and 15 regrowth). Lines and shaded areas are mean values and $95 \%$ confidence intervals from linear models illustrating trends in basal area with increasing mammal diversity. Points with different shapes represent different regrowth plot types.

show that highly diverse Guyana Shield wet forests can take longer to establish ${ }^{13}$. With basal area of control plots dominated by large trees it seems likely that many decades will be necessary for forest structure (total basal area, proportion of large trees) to return to pre-disturbance values.

The success of active and passive restoration can depend on ecological conditions ${ }^{46}$. We found topography was the most informative model for explaining patterns in number of tress, tree basal area and proportion of small trees (Table 3, Fig. 2). Differences in altitude and slope have been shown to affect floristic structure of tropical forests from local to regional scales ${ }^{16,35,43,47-49}$. Indeed, even relatively small variations in topography can generate changes in local-scale soil chemistry, hydrology and microclimate ${ }^{47,50}$. The effects of topography do not operate in isolation from hydrology and the increased numbers of small trees and tree biomass with increasing altitude (Fig. 3) agree with previous studies that show trees grow more slowly in more low lying (and often more waterlogged) terrain ${ }^{43}$. It remains uncertain how differences in soil type may affect regrowth trajectories and additional experimental studies are needed to examine the relative contributions of soil, hydrology and topography.

We found a weak association between mammal diversity and regrowth forest structure. Previous studies in a nearby protected area show that this group of mammals (mid- to large-bodied Artiodactyla, Perissodactyla and Rodentia) are more strongly associated with factors such as access to water ${ }^{51}$ and altitude ${ }^{51,52}$. A recent study also showed that mammal abundances were more strongly associated with phenology (fruit fall) than basal area along $10 \mathrm{~km}$ of forest in the western Guyana Shied ${ }^{53}$. Additionally, regrowth class was found to be the primary driver of mammal species encountered independent of forest cover ${ }^{54}$. For example the number of species detected in control and regrowth plots (all with forest cover $>87 \%$ ) varied between 1 and 6 (Fig. 4). Mid- to large-bodied seed dispersers are a critical component of Amazon forests ${ }^{18,19,25}$ and are also widespread and ubiquitous across myriad Amazonian forest types ${ }^{55-57}$. The eight species are therefore not strictly dependent on the quality of forest habitat compared with other more specialist groups such as primates ${ }^{58}$. The lack of a strong relationship between diversity of these eight mammal seed dispersers and forest structure attributes (i.e. overall basal area and proportion of small trees) is therefore to be expected.

Decades of research show that myriad edge effects can extend up to $150 \mathrm{~m}$ in fragmented Amazon forests ${ }^{59,60}$. Considering the range of expect edge-effects it is highly probable that the natural regeneration and/or restoration of regrowth habitats in Amazon smallholdings (typically < 100 ha) will strongly depend on species ecological responses to habitat edges ${ }^{61}$. Previous studies show that edge effects increase mortality of large trees, which in turn has major impacts on forest ecosystems ${ }^{62}$. In highly fragmented areas edge-effects can drive tree communities through a process of "retrogressive succession" 63 and toward an early successional state that may persist indefinitely. This early successional state can be characterized by functional and structural differences in that larger slower-growing tree species with high wood density tend to decline whereas faster-growing tree and liana species with lower wood density increase ${ }^{63,64}$. The decline in the number and basal area of large trees from our 


\begin{tabular}{|c|c|c|c|c|c|c|c|}
\hline Forest structure & Model $^{\mathrm{a}}$ & Dev. Exp & Loglik & BIC & AIC & $\Delta \mathrm{AIC}$ & $\mathrm{W}_{\mathrm{i}} \mathrm{AIC}^{\mathrm{b}}$ \\
\hline \multicolumn{8}{|l|}{ Trees } \\
\hline & Topography & 60.5 & -100.6 & 231.9 & 219.3 & 0.0 & 0.91 \\
\hline & Regrowth class & 49.8 & -105.1 & 234.1 & 224.3 & 5.0 & 0.07 \\
\hline & Mammals & 51.3 & -104.7 & 240.0 & 227.3 & 8.1 & 0.02 \\
\hline & Hydrology & 45.8 & -106.3 & 243.1 & 230.5 & 11.3 & 0.00 \\
\hline & Time & 42.9 & -107.0 & 244.7 & 232.1 & 12.8 & 0.00 \\
\hline & Plot & 6.5 & -114.4 & 239.1 & 234.9 & 15.6 & 0.00 \\
\hline \multicolumn{8}{|c|}{ Proportion small trees } \\
\hline & Topography & 75.2 & -64.3 & 155.7 & 144.5 & 0.0 & 0.96 \\
\hline & Hydrology & 70.4 & -67.5 & 162.2 & 151.0 & 6.5 & 0.04 \\
\hline & Mammals & 66.4 & -70.2 & 167.6 & 156.4 & 11.9 & 0.00 \\
\hline & Time & 65.1 & -71.0 & 169.3 & 158.1 & 13.6 & 0.00 \\
\hline & Plot & 53.7 & -78.7 & 164.3 & 161.5 & 17.0 & 0.00 \\
\hline & Regrowth class & 55.4 & -77.6 & 175.6 & 167.2 & 22.7 & 0.00 \\
\hline \multicolumn{8}{|c|}{ Proportion large trees } \\
\hline & Plot & 54.9 & -30.5 & 67.8 & 65.0 & 0.0 & 0.88 \\
\hline & Regrowth class & 60.6 & -28.9 & 78.2 & 69.8 & 4.8 & 0.08 \\
\hline & Mammals & 62.9 & -28.3 & 83.7 & 72.5 & 2.8 & 0.02 \\
\hline & Time & 62.8 & -28.3 & 83.8 & 72.5 & 2.8 & 0.02 \\
\hline & Topography & 54.7 & -30.6 & 88.5 & 77.3 & 7.5 & 0.00 \\
\hline & Hydrology & 52.8 & -31.1 & 89.5 & 78.3 & 8.5 & 0.00 \\
\hline \multicolumn{8}{|l|}{ BA all trees } \\
\hline & Topography & 80.7 & -100.9 & 232.3 & 220.4 & 0.0 & 0.89 \\
\hline & Regrowth class & 72.9 & -105.8 & 235.4 & 225.6 & 5.2 & 0.06 \\
\hline & Plot & 62.9 & -110.4 & 231.0 & 226.8 & 6.4 & 0.04 \\
\hline & Mammals & 71.7 & -106.4 & 243.4 & 230.8 & 10.4 & 0.01 \\
\hline & Time & 69.3 & -107.6 & 245.8 & 233.2 & 12.8 & 0.00 \\
\hline & Hydrology & 66.0 & -109.1 & 248.8 & 236.2 & 15.9 & 0.00 \\
\hline \multicolumn{8}{|l|}{ BA large trees } \\
\hline & Plot & 58.3 & -61.5 & 133.1 & 128.9 & 0.0 & 0.87 \\
\hline & Regrowth class & 67.1 & -59.9 & 143.5 & 133.7 & 4.8 & 0.08 \\
\hline & Hydrology & 70.9 & -59.0 & 148.7 & 136.1 & 7.1 & 0.02 \\
\hline & Mammals & 70.4 & -59.2 & 148.9 & 136.3 & 7.4 & 0.02 \\
\hline & Time & 65.7 & -60.1 & 150.9 & 138.3 & 9.4 & 0.01 \\
\hline & Topography & 60.8 & -61.0 & 152.7 & \begin{tabular}{|l|l}
140.1 \\
\end{tabular} & 11.2 & 0.00 \\
\hline
\end{tabular}

Table 3. Summary of the Generalized Linear Models created to explain forest structure in 30 plots (15 control and 15 regrowth). Models ordered by decreasing AIC (Akaike Information Criterion) values. ${ }^{\text {a Models used }}$ to explain forest structure. All models contained plot type (control/regrowth) as categorical factor. Variables and associated estimates in the different models can be found as Supplementary Information Table S2 online. ${ }^{\mathrm{b}}$ Akaike weights $\left(\mathrm{W}_{\mathrm{i}}\right)$ from largest to smallest.

control plots along 20-25 year old edges suggest that retrogressive succession may establish even in relatively un-fragmented areas surrounded by extensive forest cover.

More empirical evidence is however required to strengthen support for the retrogressive succession hypothesis in relatively unfragmented Amazon landscapes. Additional studies are needed that focus on quantifying the distribution of other structural and functional components of tropical forests such as lianas and short-lived pioneers, changes in forest stratification and convergence of tree assemblages ${ }^{63-65}$. There also remained uncertainty in our models that could be reduced through increased sampling effort. Studies show that within and among plot uncertainty can be reduced by multi-plot census ${ }^{66}$, with smaller plot sizes (e.g. $<0.25$ ha) requiring more replicates ${ }^{66,67}$. An increased long-term monitoring effort is therefore necessary to enable a more robust understanding of the forest structure dynamics across our study sites.

Our findings provide an early warning that even under a best case scenario there is potential for "retrogressive succession". We found not only a lack of large trees in regrowth plots but also that large tree basal declined in older late-regrowth control plots. We suggest that this decline in large tress may be the primary driver of differences between regrowth and old growth forest and as such represent an unquantified component of resilience and time to recovery of Neotropical secondary forests. We also suggest that the continued presence of mid-and large bodied mammal seed dispersers in the study area are likely to be vital in order to avoid such "retrogressive succession". 

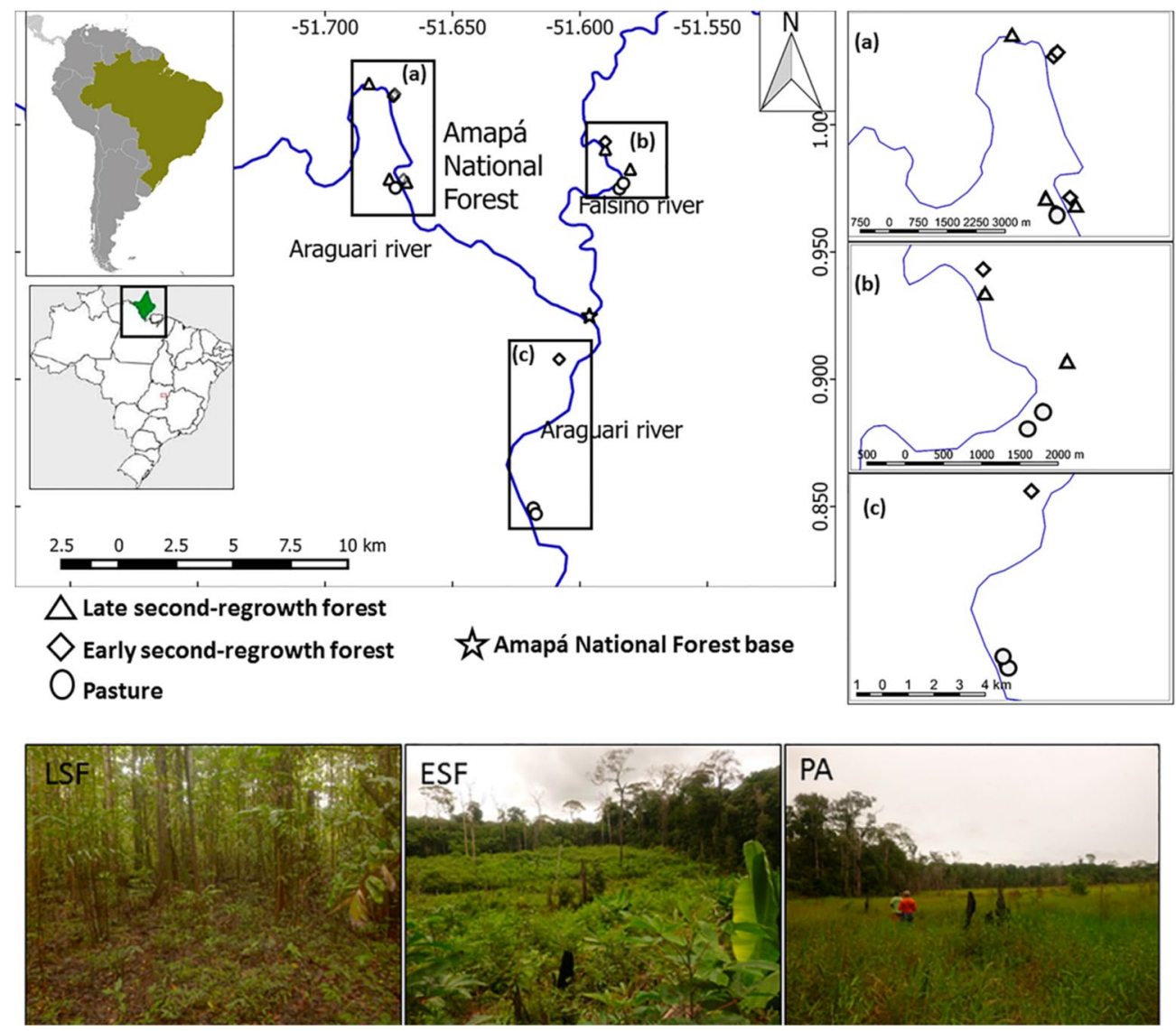

Figure 5. Map of the study area in the eastern Amazon. Showing the location of 15 study sites, grouped into three regrowth stages in the smallholder properties close to rivers (solid blue lines): late second-regrowth forest (LSF, triangles), early second-regrowth forest (ESF, squares) and pasture (PA, circles).

\section{Methods}

Ethics statement. All methods were carried out in accordance with relevant guidelines and regulations. Fieldwork and data collection was conducted under research permit numbers SISBIO 40355-1, 47859-1 and 47859-2 to DN, issued by the Brazilian Ministério do Meio Ambiente ("MMA"). Data collection used noninvasive, remotely activated camera traps and did not involve direct contact or interaction with animals, thus no ethical approval was required. Interviews with local residents were approved by Brazilian Ministério do Meio Ambiente (SISBIO permits 45034-1, 45034-2, 45034-3) and the Ethics Committee in Research from the Federal University of Amapá (UNIFAP) (CAAE 42064815.5.0000.0003, Permit number 1.013.843). Interviews were conducted with residents that were both (1) willing to be interviewed (written informed consent was obtained from all interviewees) and (2) aware of the site history.

Study area. Our study took place in 15 areas of regrowth on smallholder properties ${ }^{54,68}$ in the center of the Brazilian State of Amapá (Fig. 5). The properties were located within the Uatumã-Trombetas moist forest ecoregion $^{69}$ (tropical \& subtropical moist broadleaf forests biome), which includes the floristic transition from the Guayana Shield to the Amazon Basin. The local forests are part of the eastern Amazon Guianan forests ${ }^{70}$ and consist predominantly of never-flooded closed canopy "terra firme" tropical rainforest vegetation dominated by members of the Fabaceae, Sapotaceae, Lecythidaceae and Lauraceae ${ }^{71}$. Canopy trees typically reach a height of 25-35 m interspersed with emergent trees reaching up to $50-\mathrm{m}^{71}$. The soil is predominantly low-fertility oxisols, including a mix of red, yellow and red-yellow latosols following the Brazilian soil classification system ${ }^{72}$. The regional climate is classified by Koppen-Geiger as Am (Equatorial monsoon) ${ }^{73}$, with annual rainfall greater than $2500 \mathrm{~mm}^{74}$. The driest months are September to November (total monthly rainfall $<150 \mathrm{~mm}$ ) and the wettest months from February to April (total monthly rainfall $>300 \mathrm{~mm})^{74}$.

The State of Amapá has the lowest deforestation rate in Brazil and $>70 \%$ of the Amapá receives some form of legal protection. There is no large scale agricultural developments or monocultures along the waterways and properties retain typically small $(<1000 \mathrm{ha})$ areas of opened land, which are cleared for small scale family agriculture, which focuses on acai (Euterpe oleraceae ${ }^{75}$ ), small scale production of fruits and vegetables for sustenance and limited commercial sale of regional produce (e.g. manioc flour) in local markets. There are some 54 properties upstream of the nearest town (Porto Grande ${ }^{76}$ ). There has never been any expansive clearcutting in 
the region and there are no monocultures (e.g. soy) or cattle production. All sites were at least $26 \mathrm{~km}$ from the nearest town by river, and all sites are surrounded by matrix of continuous closed canopy forest cover (Table 2). Pesticides and/or herbicides had never been used at any of the sites.

As described previously $y^{54,68}$ the 15 smallholder properties were all lowland (90-120 masl) and selected based on differences in land-use histories and forest succession/regrowth stage. All sites were close (110-554 m, Table 2) to 100-200 m wide rivers that are navigable by motorized boats, but due to riverbank formation the sites are never flooded. These 15 sites were grouped into three regrowth classes based on the land-use history: late secondregrowth forest $(\mathrm{N}=5$, most recent human disturbance between 20 and 25 years), early second-regrowth $(\mathrm{N}=5$, most recent human disturbance between 1 and 5 years), and pasture $(\mathrm{N}=5$, recently cleared and abandoned pasture areas dominated by grasses/herbs but that had never been used to raise livestock, with the most recent disturbance between 1 and 17 years). Each of the 15 regrowth sites was paired with a nearby (60 to $150 \mathrm{~m}$ ) control site i.e. 20-30 m tall terra-firme forest site without a history of mechanized timber extraction. We did not record any evidence of logging or hunting in the control areas. We therefore assume that there were minimal anthropogenic impacts in the control sites that if present did not generate any systematic bias in our comparisons between regrowth stages. To reduce the possible confounding influence of edge effects that are known to strongly influence the distribution of trees in Neotropical forests, all regrowth and control sites were established at a standardized distance (approximately $30 \mathrm{~m}$ ) from the nearest control-regrowth habitat edge.

Forest structure. Data were collected from May to August 2016. Forest structure data (i.e., number of trees and basal area) were obtained from plots measuring $50 \times 10 \mathrm{~m}\left(500 \mathrm{~m}^{2} / 0.05 \mathrm{ha}\right)$, at each of the 30 points, totaling 1.5 hectare. This plot size was selected as it has been widely used to examine structural changes in tropical forests $^{19,42,43,77}$ and several of the regrowth areas were too small (Table 2) to enable the establishment of larger spatially independent plots. We obtained five measures (responses) to characterize the forest structure in each plot. These were selected based on previous studies that show their appropriateness to distinguish attributes of regrowth/successional stages related to biodiversity of Amazon forests ${ }^{13,45,78,79}$. The number of all trees $\geq 10 \mathrm{~cm}$ DBH (diameter at breast height at a standard $1.3 \mathrm{~m}$ above ground, or above tallest root buttress) was used to quantify the tree density in each plot $\left(\mathrm{m}^{2}\right)$. This count included all trees which had at least half of their basal trunk inside the plot. The proportion of small $(10-20 \mathrm{~cm} \mathrm{DBH})$ trees was calculated to represent the expected increase of younger trees in regrowth areas. The proportion of large $(>60 \mathrm{~cm} \mathrm{DBH})$ trees was calculated as this is known as an important characteristic of mature/late succession areas ${ }^{45,79}$. We also calculated the basal area of all and large trees as this is known to be strongly correlated with tropical tree biomass ${ }^{36,80}$.

Explanatory variables. A total of 10 variables (Table 1) were used to build models to represent 5 working hypotheses (topography, hydrology, regrowth class, time and mammal diversity) that based on the findings from previous studies were likely to explain the observed patterns ${ }^{13,28,36,41,42,81}$. We chose to work with mainstream, widely available environmental variables. Four of these (the topographic and hydrographic model variables) were computed from remotely sensed digital terrain model (SRTM-DTM): altitude (masl), slope, TWI (Topographic wetness index), DND (Distance to Network Drainage) calculated from the interaction between HAND (Height above network drainage) and HDND (Horizontal distance to network drainage). The time model included years since the regrowth site was opened and years since last use, both of which were obtained from interviews with local landowners.

Mammal functional diversity was obtained from a camera-trap survey conducted at the same time (May to September 2016) and in the same plots as forest structure was sampled ${ }^{54}$. Camera traps equipped with infrared triggers (Bushnell Trophy Cam, 8MP, Overland Park, KS, USA) were installed in each of the 30 plots following standardized protocols ${ }^{51,52,82}$. This camera trap survey [full details provide in ${ }^{54}$ ] including a sampling effort of 827 camera-trap days (450 and 377 camera-trap days, control and regrowth sites respectively) was used to estimate functional diversity of eight terrestrial mammal seed dispersers (Cuniculus paca, Dasyprocta leporina, Myoprocta acouchy, Mazama americana, M. nemorivaga, Pecari tajacu, Tayassu pecari and Tapirus terrestris).

Data analysis. Tree Basal Area in each plot was obtained as the sum of the basal area value for each individual tree derived from the $\mathrm{DBH}$ of each tree following the formula $\mathrm{BA}$ (basal area in $\mathrm{m}^{2}$ ) $=0.00007854 \times \mathrm{DBH}^{2}$ (constant obtained by solving the following equation to obtain BA in $\mathrm{m}^{2}$ from the DBH measured in $\mathrm{cm}^{78}$ ):

$$
\mathrm{BA}=\frac{\pi \times(\mathrm{DBH} / 2)^{2}}{10000}
$$

We calculated basal area of all and large $(>60 \mathrm{~cm} \mathrm{DBH})$ living trees ${ }^{78,79,81}$. We also calculated the proportion of small stems (10-20 cm DBH trees) as this has been shown to be an important measure of stand structure in forest regrowth areas ${ }^{35,78}$.

To represent diversity of terrestrial mammal seed dispersers we calculated a richness and functional diversity (FD) value for each of the 30 plots $^{54}$. Richness was calculated as the observed number of species (hereafter "species richness") at each plot. Although there are many diversity metrics, we chose species richness as it is widely used and clearly interpretable ${ }^{83,84}$ and with relatively few (eight) species and 30 plots there were strong correlations between species richness values and alternative diversity metrics such as Shannon and Simpson diversity (Spearman rho $>0.89$ ). We used Functional Dispersion (FDis) ${ }^{85}$ as an index of functional diversity as it is not strongly influenced by outliers, accounts for relative abundances, is unaffected by species richness and can be calculated from any distance/dissimilarity measure ${ }^{85,86}$. Functional Dispersion was estimated with the dbFD function ${ }^{86}$ using default settings. 
To examine patterns in forest structure attributes we used Generalized Linear Models. We used an information theoretic model averaging framework ${ }^{87}$ to compare five models representing the five non-mutually exclusive working hypotheses-topography, hydrology, regrowth class, time and mammal diversity (see Table 1 for variable description and ecological relevance). There were only weak insignificant correlations between regrowth classes and the topographic and hydrological variables (all pairwise Polyserial correlation coefficients ${ }^{88}$ : rho $<0.45$, $P>0.05$ ), which supports a lack of systematic bias in the distribution of topographic and hydrologic variables across the three regrowth classes. We evaluated models based on their information content, as measured by AIC-Akaike Information Criterion. The relative importance of the models was measured by the models Akaike weights (Burnham and Anderson ${ }^{87}$, pp. 75-77, 167-172), which is a scaled measure of the likelihood ratio that ranges between 0 (least important) and 1 (most important). None of the unexplained variation (model residuals) was related to the geographic distance among plots so we did not need to control for spatial dependence. All analysis were conducted using the $\mathrm{R}$ language and environment for statistical computing ${ }^{89}$, with base functions and functions available in the following packages: vegan ${ }^{90}$, ggplot $2^{91}, \operatorname{MuMIn}^{92}$, and tweedie ${ }^{93}$.

\section{Data availability}

The raw forest structure and environmental data used in the analysis of this study have been deposited in the OSF-Center for Open Science at https://doi.org/10.17605/OSF.IO/MC27U and via figshare at https://doi. org/10.6084/m9.figshare.13547909.v1.

Received: 20 April 2020; Accepted: 28 January 2021

Published online: 09 February 2021

\section{References}

1. Hansen, M. C. et al. High-resolution global maps of 21st-century forest cover change. Science 342, 850-853. https://doi.org/10.1126/ science.1244693 (2013).

2. Chazdon, R. L. \& Guariguata, M. R. Natural regeneration as a tool for large-scale forest restoration in the tropics: prospects and challenges. Biotropica 48, 716-730. https://doi.org/10.1111/btp.12381 (2016).

3. Holl, K. D. Restoring tropical forests from the bottom up. Science 355, 455-456. https://doi.org/10.1126/science.aam5432 (2017).

4. Brancalion, P. H. S. et al. Balancing economic costs and ecological outcomes of passive and active restoration in agricultural landscapes: the case of Brazil. Biotropica 48, 856-867. https://doi.org/10.1111/btp.12383 (2016).

5. Foley, J. A. et al. Amazonia revealed: forest degradation and loss of ecosystem goods and services in the Amazon Basin. Front. Ecol. Environ. 5, 25-32. https://doi.org/10.1890/1540-9295(2007)5[25:ARFDAL]2.0.CO;2 (2007).

6. Montibeller, B., Kmoch, A., Virro, H., Mander, Ü. \& Uuemaa, E. Increasing fragmentation of forest cover in Brazil's Legal Amazon from 2001 to 2017. Sci. Rep. 10, 5803. https://doi.org/10.1038/s41598-020-62591-x (2020).

7. Csillik, O., Kumar, P., Mascaro, J., O’Shea, T. \& Asner, G. P. Monitoring tropical forest carbon stocks and emissions using Planet satellite data. Sci. Rep. 9, 17831. https://doi.org/10.1038/s41598-019-54386-6 (2019).

8. Nunes, S. et al. Uncertainties in assessing the extent and legal compliance status of riparian forests in the eastern Brazilian Amazon. Land Use Policy 82, 37-47. https://doi.org/10.1016/j.landusepol.2018.11.051 (2019).

9. Rocha, G. P. E., Vieira, D. L. M. \& Simon, M. F. Fast natural regeneration in abandoned pastures in southern Amazonia. For. Ecol. Manag. 370, 93-101. https://doi.org/10.1016/j.foreco.2016.03.057 (2016).

10. Rodrigues, S. B. et al. Direct seeded and colonizing species guarantee successful early restoration of South Amazon forests. For. Ecol. Manag. 451, 117559. https://doi.org/10.1016/j.foreco.2019.117559 (2019).

11. Fearnside, P. M. Deforestation in Brazilian Amazonia: history, rates, and consequences. Conserv. Biol. 19, 680-688. https://doi.org /10.1111/j.1523-1739.2005.00697.x (2005).

12. Laurance, W. F. et al. Rain forest fragmentation and the proliferation of sucessional trees. Ecology 87, 469-482. https://doi. org/10.1890/05-0064 (2006).

13. Poorter, L. et al. Biomass resilience of Neotropical secondary forests. Nature 530, 211-214. https://doi.org/10.1038/nature16512 (2016).

14. Camargo, J. L. C., Ferraz, I. D. K. \& Imakawa, A. M. Rehabilitation of degraded areas of central Amazonia using direct sowing of forest tree seeds. Restor. Ecol. 10, 636-644. https://doi.org/10.1046/j.1526-100X.2002.01044.x (2002).

15. Guariguata, M. R. \& Ostertag, R. Neotropical secondary forest succession: changes in structural and functional characteristics. For. Ecol. Manag. 148, 185-206. https://doi.org/10.1016/S0378-1127(00)00535-1 (2001).

16. Crouzeilles, R. et al. A global meta-analysis on the ecological drivers of forest restoration success. Nat. Commun. 7, 11666. https ://doi.org/10.1038/ncomms11666 (2016).

17. Chazdon, R. L. et al. The potential for species conservation in tropical secondary forests. Conserv. Biol. 23, 1406-1417. https://doi. org/10.1111/j.1523-1739.2009.01338.x (2009).

18. Peres, C. A., Emilio, T., Schietti, J., Desmouliere, S. J. \& Levi, T. Dispersal limitation induces long-term biomass collapse in overhunted Amazonian forests. Proc. Natl. Acad. Sci. USA 113, 892-897. https://doi.org/10.1073/pnas.1516525113 (2016).

19. Pessoa, M. S. et al. Deforestation drives functional diversity and fruit quality changes in a tropical tree assemblage. Perspect. Plant Ecol. Evol. Syst. 28, 78-86. https://doi.org/10.1016/j.ppees.2017.09.001 (2017).

20. Bowen, M. E., McAlpine, C. A., House, A. P. \& Smith, G. C. Regrowth forests on abandoned agricultural land: a review of their habitat values for recovering forest fauna. Biol. Cons. 140, 273-296. https://doi.org/10.1016/j.biocon.2007.08.012 (2007).

21. Chazdon, R. L. \& Uriarte, M. Natural regeneration in the context of large-scale forest and landscape restoration in the tropics. Biotropica 48, 709-715. https://doi.org/10.1111/btp.12409 (2016).

22. Neuschulz, E. L., Mueller, T., Schleuning, M. \& Böhning-Gaese, K. Pollination and seed dispersal are the most threatened processes of plant regeneration. Sci. Rep. 6, 29839. https://doi.org/10.1038/srep29839 (2016).

23. Stoner, K. E., Riba-Hernández, P., Vulinec, K. \& Lambert, J. E. The role of mammals in creating and modifying seedshadows in tropical forests and some possible consequences of their elimination. Biotropica 39, 316-327. https://doi.org/10.111 1/j.1744-7429.2007.00292.x (2007).

24. Griffiths, H. M., Bardgett, R. D., Louzada, J. \& Barlow, J. The value of trophic interactions for ecosystem function: dung beetle communities influence seed burial and seedling recruitment in tropical forests. Proc. R. Soc. B 283, 20161634. https://doi.org/10.1098/ rspb.2016.1634 (2016).

25. Asquith, N. M. \& Mejía-Chang, M. Mammals, edge effects, and the loss of tropical forest diversity. Ecology 86, 379-390. https:// doi.org/10.1890/03-0575 (2005).

26. Beck, H., Snodgrass, J. W. \& Thebpanya, P. Long-term exclosure of large terrestrial vertebrates: Implications of defaunation for seedling demographics in the Amazon rainforest. Biol. Cons. 163, 115-121. https://doi.org/10.1016/j.biocon.2013.03.012 (2013). 
27. Paine, C. E., Beck, H. \& Terborgh, J. How mammalian predation contributes to tropical tree community structure. Ecology 97, 3326-3336. https://doi.org/10.1002/ecy.1586 (2016).

28. Sobral, M. et al. Mammal diversity influences the carbon cycle through trophic interactions in the Amazon. Nat. Ecol. Evol. 1, 1670-1676. https://doi.org/10.1038/s41559-017-0334-0 (2017).

29. Bascompte, J. \& Jordano, P. Plant-animal mutualistic networks: the architecture of biodiversity. Annu. Rev. Ecol. Evol. Syst. 38 , 567-593. https://doi.org/10.1146/annurev.ecolsys.38.091206.095818 (2007).

30. Wunderle, J. M. The role of animal seed dispersal in accelerating native forest regeneration on degraded tropical lands. For. Ecol. Manag. 99, 223-235. https://doi.org/10.1016/S0378-1127(97)00208-9 (1997).

31. Fragoso, J. M. V. Tapir-generated seed shadows: scale-dependent patchiness in the Amazon Rain Forest. J. Ecol. 85, 519-529. https ://doi.org/10.2307/2960574 (1997).

32. Hibert, F. et al. Unveiling the diet of elusive rainforest herbivores in next generation sequencing era? The tapir as a case study. PLoS ONE 8, e60799. https://doi.org/10.1371/journal.pone.0060799 (2013).

33. Terborgh, J. et al. Tree recruitment in an empty forest. Ecology 89, 1757-1768. https://doi.org/10.1890/07-0479.1 (2008).

34. Wright, S. J. et al. The plight of large animals in tropical forests and the consequences for plant regeneration. Biotropica 39, 289-291. https://doi.org/10.1111/j.1744-7429.2007.00293.x (2007).

35. Molto, Q. et al. Predicting tree heights for biomass estimates in tropical forests; a test from French Guiana. Biogeosciences 11, 3121-3130. https://doi.org/10.5194/bg-11-3121-2014 (2014).

36. Letcher, S. G. \& Chazdon, R. L. Rapid recovery of biomass, species richness, and species composition in a forest chronosequence in Northeastern Costa Rica. Biotropica 41, 608-617. https://doi.org/10.1111/j.1744-7429.2009.00517.x (2009).

37. Körner, C. The use of 'altitude' in ecological research. Trends Ecol. Evol. 22, 569-574. https://doi.org/10.1016/j.tree.2007.09.006 (2007).

38. Beven, K. \& Kirkby, M. J. A physically based, variable contributing area model of basin hydrology. Hydrol. Sci. J. 24, 43-69. https ://doi.org/10.1080/02626667909491834 (1979).

39. Campling, P., Gobin, A. \& Feyen, J. Logistic modeling to spatially predict the probability of soil drainage classes. Soil Sci. Soc. Am. J. 66, 1390-1401. https://doi.org/10.2136/sssaj2002.1390 (2002).

40. Nobre, A. D. et al. Height above the nearest drainage: a hydrologically relevant new terrain model. J. Hydrol. 404, 13-29. https:// doi.org/10.1016/j.jhydrol.2011.03.051 (2011).

41. Schietti, J. et al. Vertical distance from drainage drives floristic composition changes in an Amazonian rainforest. Plant Ecol. Diver. 7, 241-253. https://doi.org/10.1080/17550874.2013.783642 (2014).

42. Gehring, C., Denich, M. \& Vlek, P. L. G. Resilience of secondary forest regrowth after slash-and-burn agriculture in central Amazonia. J. Trop. Ecol. 21, 519-527. https://doi.org/10.1017/S0266467405002543 (2005).

43. Feldpausch, T. R., Riha, S. J., Fernandes, E. C. M. \& Wandelli, E. V. Development of forest structure and leaf area in secondary forests regenerating on abandoned pastures in Central Amazônia. Earth Interact. 9, 1-22. https://doi.org/10.1175/EI140.1 (2005).

44. Luskin, M. S., Ickes, K., Yao, T. L. \& Davies, S. J. Wildlife differentially affect tree and liana regeneration in a tropical forest: an 18-year study of experimental terrestrial defaunation versus artificially abundant herbivores. J. Appl. Ecol. 56, 1379-1388. https:// doi.org/10.1111/1365-2664.13378 (2019).

45 Lu, D., Mausel, P., Brondizio, E. \& Moran, E. Classification of successional forest stages in the Brazilian Amazon basin. Forest Ecol. Manag. 181, 301-312. https://doi.org/10.1016/S0378-1127(03)00003-3 (2003).

46. Crouzeilles, R. et al. Ecological restoration success is higher for natural regeneration than for active restoration in tropical forests. Science Advances 3, e1701345. https://doi.org/10.1126/sciadv.1701345 (2017).

47 de Castilho, C. V. et al. Variation in aboveground tree live biomass in a central Amazonian Forest: Effects of soil and topography. Forest Ecol. Manag. 234, 85-96. https://doi.org/10.1016/j.foreco.2006.06.024 (2006).

48. Jucker, T. et al. Topography shapes the structure, composition and function of tropical forest landscapes. Ecol. Lett. 21, 989-1000. https://doi.org/10.1111/ele.12964 (2018).

49. Fortunel, C. et al. Topography and neighborhood crowding can interact to shape species growth and distribution in a diverse Amazonian forest. Ecology 99, 2272-2283. https://doi.org/10.1002/ecy.2441 (2018).

50. Tiessen, H., Chacon, P. \& Cuevas, E. Phosphorus and nitrogen status in soils and vegetation along a toposequence of dystrophic rainforests on the upper Rio Negro. Oecologia 99, 145-150. https://doi.org/10.1007/BF00317095 (1994).

51. Paredes, O. S. L., Norris, D., Oliveira, T. G. D. \& Michalski, F. Water availability not fruitfall modulates the dry season distribution of frugivorous terrestrial vertebrates in a lowland Amazon forest. PLOS ONE 12, e0174049. https://doi.org/10.1371/journ al.pone.0174049 (2017).

52. Michalski, L. J., Norris, D., de Oliveira, T. G. \& Michalski, F. Ecological relationships of meso-scale distribution in 25 neotropical vertebrate species. PLoS ONE 10, e0126114. https://doi.org/10.1371/journal.pone.0126114 (2015).

53. Mendes Pontes, A. R. Tree reproductive phenology determines the abundance of medium-sized and large mammalian assemblages in the Guyana shield of the Brazilian Amazonia. Anim. Biodiver. Conserv. 43(1), 9-26. https://doi.org/10.32800/abc.2020.43.0009 (2020).

54. Arévalo-Sandi, A., Bobrowiec, P. E. D., Rodriguez Chuma, V. J. U. \& Norris, D. Diversity of terrestrial mammal seed dispersers along a lowland Amazon forest regrowth gradient. PLoS ONE 13, e0193752. https://doi.org/10.1371/journal.pone.0193752 (2018).

55 Arita, H. T., Robinson, J. G. \& Redford, K. Rarity in Neotropical forest mammals and its ecological correlates. Conserv. Biol. 4, 181-192. https://doi.org/10.1111/j.1523-1739.1990.tb00107.x (1990).

56. Peres, C. A. \& Palacios, E. Basin-wide effects of game harvest on vertebrate population densities in Amazonian forests: implications for animal-mediated seed dispersal. Biotropica 39, 304-315. https://doi.org/10.1111/j.1744-7429.2007.00272.x (2007).

57. Emmons, L. H. \& Feer, F. Neotropical Rainforest Mammals: A Field Guide (The University of Chicago Press, Chicago, 1997).

58. Michalski, F., Michalski, L. J. \& Barnett, A. A. Environmental determinants and use of space by six Neotropical primates in the northern Brazilian Amazon. Stud. Neotrop. Fauna Environ. 52, 187-197. https://doi.org/10.1080/01650521.2017.1335276 (2017).

59. Laurance, W. F. et al. Ecosystem decay of Amazonian forest fragments: a 22-year investigation. Conserv. Biol. 16, 605-618. https ://doi.org/10.1046/j.1523-1739.2002.01025.x (2002).

60. Norris, D., Peres, C. A., Michalski, F. \& Hinchsliffe, K. Terrestrial mammal responses to edges in Amazonian forest patches: a study based on track stations. Mammalia 72, 15-23. https://doi.org/10.1515/mamm.2008.002 (2008).

61. Martínez-Ramos, M. et al. Natural forest regeneration and ecological restoration in human-modified tropical landscapes. Biotropica 48, 745-757. https://doi.org/10.1111/btp.12382 (2016).

62. Laurance, W. F., Delamônica, P., Laurance, S. G., Vasconcelos, H. L. \& Lovejoy, T. E. Rainforest fragmentation kills big trees. Nature 404, 836-836. https://doi.org/10.1038/35009032 (2000).

63. Tabarelli, M., Lopes, A. V. \& Peres, C. A. Edge-effects drive tropical forest fragments towards an early-successional system. Biotropica 40, 657-661. https://doi.org/10.1111/j.1744-7429.2008.00454.x (2008).

64. Santos, B. A. et al. Drastic erosion in functional attributes of tree assemblages in Atlantic forest fragments of northeastern Brazil. Biol. Cons. 141, 249-260. https://doi.org/10.1016/j.biocon.2007.09.018 (2008).

65. Melo, F. P. L., Arroyo-Rodríguez, V., Fahrig, L., Martínez-Ramos, M. \& Tabarelli, M. On the hope for biodiversity-friendly tropical landscapes. Trends Ecol. Evol. 28, 462-468. https://doi.org/10.1016/j.tree.2013.01.001 (2013).

66 Malhi, Y. et al. Error propagation and scaling for tropical forest biomass estimates. Philos. Trans. R. Soc. Lond. Ser. B Biol. Sci. 359, 409-420. https://doi.org/10.1098/rstb.2003.1425 (2004). 
67. Keller, M., Palace, M. \& Hurtt, G. Biomass estimation in the Tapajos National Forest, Brazil: examination of sampling and allometric uncertainties. For. Ecol. Manag. 154, 371-382. https://doi.org/10.1016/S0378-1127(01)00509-6 (2001).

68. Arévalo-Sandi, A. R. \& Norris, D. Short term patterns of germination in response to litter clearing and exclosure of large terrestrial vertebrates along an Amazon forest regrowth gradient. Glob. Ecol. Conserv. 13, e00371. https://doi.org/10.1016/j.gecco.2017.e0037 1 (2018).

69. David, M. O. et al. Terrestrial ecoregions of the world: a new map of life on earth. Bioscience 51, 933-938. https://doi. org/10.1641/0006-3568(2001)051[0933:TEOTWA]2.0.CO;2 (2001).

70 ter Steege, H. et al. An analysis of the floristic composition and diversity of Amazonian forests including those of the Guiana Shield. J. Trop. Ecol. 16, 801-828 (2000).

71. Batista, A. P. B. et al. Caracterização estrutural em uma floresta de terra firme no estado do Amapá, Brasil. Pesq. flor. bras 35, 21-33 (2015).

72 Eswaran, H., Ahrens, R., Rice, T. J. \& Stewart, B. A. Soil Classification: A Global Desk Reference (CRC Press, Boca Raton, 2002).

73. Kottek, M., Grieser, J., Beck, C., Rudolf, B. \& Rubel, F. World map of the Koppen-Geiger climate classification updated. Meteorol. Z. 15, 259-263. https://doi.org/10.1127/0941-2948/2006/0130 (2006).

74. ANA. Sistema de Monitoramento Hidrológico (Hydrological Monitoring System). Agência Nacional de Águas[[nl]]National Water Agency, Available at http://www.hidroweb.ana.gov.br, 2017).

75 Norris, D., Rodriguez Chuma, V. J. U., Arevalo-Sandi, A. R., Landazuri Paredes, O. S. \& Peres, C. A. Too rare for non-timber resource harvest? Meso-scale composition and distribution of arborescent palms in an Amazonian sustainable-use forest. Forest Ecol. Manag. 377, 182-191. https://doi.org/10.1016/j.foreco.2016.07.008 (2016).

76. Norris, D. \& Michalski, F. Socio-economic and spatial determinants of anthropogenic predation on Yellow-spotted River Turtle, Podocnemis unifilis (Testudines: Pelomedusidae), nests in the Brazilian Amazon: Implications for sustainable conservation and management. Zoologia (Curitiba) 30, 482-490. https://doi.org/10.1590/S1984-46702013000500003 (2013).

77 Yirdaw, E., MongeMonge, A., Austin, D. \& Toure, I. Recovery of floristic diversity, composition and structure of regrowth forests on fallow lands: implications for conservation and restoration of degraded forest lands in Laos. New Forests 50, 1007-1026. https ://doi.org/10.1007/s11056-019-09711-2 (2019).

78. McElhinny, C., Gibbons, P., Brack, C. \& Bauhus, J. Forest and woodland stand structural complexity: its definition and measurement. For. Ecol. Manag. 218, 1-24. https://doi.org/10.1016/j.foreco.2005.08.034 (2005).

79. Sist, P., Mazzei, L., Blanc, L. \& Rutishauser, E. Large trees as key elements of carbon storage and dynamics after selective logging in the Eastern Amazon. For. Ecol. Manag. 318, 103-109. https://doi.org/10.1016/j.foreco.2014.01.005 (2014).

80. Phillips, O. L. et al. Species matter: wood density influences tropical forest biomass at multiple scales. Surv. Geophys. 40, 913-935. https://doi.org/10.1007/s10712-019-09540-0 (2019).

81. Bastin, J.-F. et al. Pan-tropical prediction of forest structure from the largest trees. Glob. Ecol. Biogeogr. 27, 1366-1383. https://doi. org/10.1111/geb.12803 (2018).

82. TEAM Network. 69 (Tropical Ecology, Assessment and Monitoring Network, Center for Applied Biodiversity Science, Conservation International., Arlington, VA, USA., 2011).

83. Hortal, J., Borges, P. A. \& Gaspar, C. Evaluating the performance of species richness estimators: sensitivity to sample grain size. J. Anim. Ecol. 75, 274-287. https://doi.org/10.1111/j.1365-2656.2006.01048.x (2006).

84. Magurran, A. E. \& McGill, B. J. in Biological diversity: frontiers in measurement and assessment (eds A. E. Magurran \& B. J. McGill) Ch. 1, 1-7 (Oxford University Press, 2011).

85. Laliberté, E. \& Legendre, P. A distance-based framework for measuring functional diversity from multiple traits. Ecology 91 , 299-305. https://doi.org/10.1890/08-2244.1 (2010).

86. FD: measuring functional diversity from multiple traits, and other tools for functional ecology. R package version 1.0-12 (2014).

87. Burnham, K. P. \& Anderson, D. R. Model Selection and Multi-model Inference: A Practical Information-Theoretic Approach (Springer, Berlin, 2002).

88. Drasgow, F. in The Encyclopedia of Statistics Vol. 7 (eds S. Kotz \& N. Johnson) 68-74 (Wiley, 1986).

89. R Foundation for Statistical Computing. R: A Language and Environment for Statistical Computing. 3.6.3 (R Foundation for Statistical Computing, Vienna, 2020).

90. 90vegan: Community Ecology Package. R package version 2.4-0. https://CRAN.R-project.org/package=vegan (2016).

91. Wickham, H. ggplot2: Elegant Graphics for Data Analysis (Springer, Berlin, 2009).

92. MuMIn: multi-model inference. $\mathrm{R}$ package version 1.15.6. https://CRAN.R-project.org/package=MuMIn (2016).

93. Tweedie: Tweedie exponential family models. R package version 2.2.1. https://cran.r-project.org/web/packages/tweedie (2014).

\section{Acknowledgements}

The Instituto Chico Mendes de Conservação da Biodiversidade (ICMBio) and the Amapá National Forest staff (Érico Emed Kauano and Sueli Gomes Pontes dos Santos) and the Federal University of Amapá (UNIFAP) provided logistical support. We thank the Brazilian Ministério do Meio Ambiente ("MMA") for authorizing data collection (SISBIO permits 40355-1, 47859-1 and 47859-2). We also thank the local landowners who gave permission for data collection at their properties. We are deeply indebted to Cremilson and Cledinaldo Alves Marques and family for their dedication, commitment and assistance during the fieldwork.

\section{Author contributions}

D.N. conceived of the project; V.J.U.CR and A.A.S. collected data. V.J.U.C.R., A.A.S. and D.N. performed data analysis and interpretation. A.A.S. prepared Fig. 1. D.N. prepared Figs. 2-5. T.M.F.C. and D.N. wrote the main manuscript text. All authors reviewed and revised the manuscript.

\section{Competing interests}

The authors declare no competing interests.

\section{Additional information}

Supplementary Information The online version contains supplementary material available at https://doi. org/10.1038/s41598-021-83030-5.

Correspondence and requests for materials should be addressed to D.N.

Reprints and permissions information is available at www.nature.com/reprints.

Publisher's note Springer Nature remains neutral with regard to jurisdictional claims in published maps and institutional affiliations. 
(c) (i) Open Access This article is licensed under a Creative Commons Attribution 4.0 International cc) License, which permits use, sharing, adaptation, distribution and reproduction in any medium or format, as long as you give appropriate credit to the original author(s) and the source, provide a link to the Creative Commons licence, and indicate if changes were made. The images or other third party material in this article are included in the article's Creative Commons licence, unless indicated otherwise in a credit line to the material. If material is not included in the article's Creative Commons licence and your intended use is not permitted by statutory regulation or exceeds the permitted use, you will need to obtain permission directly from the copyright holder. To view a copy of this licence, visit http://creativecommons.org/licenses/by/4.0/.

(C) The Author(s) 2021 